\title{
Food and Water Consumption Test Code
}

National Cancer Institute

\section{Source}

National Cancer Institute. Food and Water Consumption Test Code. NCI Thesaurus.

Code C119843.

A character or string that represents the short code name of the food and water consumption assessment. 